\title{
SOURCES OF SUPPORT FOR PENSION REFORM: A CROSS-NATIONAL PERSPECTIVE
}

\author{
Michelle Dion and Andrew Roberts*
}

CRR WP 2008-23

Released: January 2009

Date Submitted: December 2008

\author{
Center for Retirement Research at Boston College \\ Hovey House \\ 140 Commonwealth Avenue \\ Chestnut Hill, MA 02467
}

Tel: 617-552-1762 Fax: 617-552-0191

\begin{abstract}
*Michelle Dion is an assistant professor at the Georgia Institute of Technology. Andrew Roberts is an assistant professor of political science and Faculty Fellow for the Institute for Policy Research at Northwestern University. The research reported herein was pursuant to a Sandell grant from the U.S. Social Security Administration (SSA) funded as part of the Retirement Research Consortium (RRC). The findings and conclusions expressed are solely those of the authors and do not represent the views of SSA, any agency of the Federal Government, the RRC, the Georgia Institute of Technology, Northwestern University, or Boston College.
\end{abstract}

(C) 2008, by Michelle Dion and Andrew Roberts. All rights reserved. Short sections of text, not to exceed two paragraphs, may be quoted without explicit permission provided that full credit, including $(\mathcal{C}$ notice, is given to the source. 


\title{
About the Center for Retirement Research
}

The Center for Retirement Research at Boston College, part of a consortium that includes parallel centers at the University of Michigan and the National Bureau of Economic Research, was established in 1998 through a grant from the Social Security

Administration. The Center's mission is to produce first-class research and forge a strong link between the academic community and decision makers in the public and private sectors around an issue of critical importance to the nation's future. To achieve this mission, the Center sponsors a wide variety of research projects, transmits new findings to a broad audience, trains new scholars, and broadens access to valuable data sources.

\author{
Center for Retirement Research at Boston College \\ Hovey House \\ 140 Commonwealth Avenue \\ Chestnut Hill, MA 02467 \\ phone: 617-552-1762 fax: 617-552-0191 \\ e-mail: crr@bc.edu \\ www.bc.edu/crr
}

\author{
Affiliated Institutions: \\ The Brookings Institution \\ Massachusetts Institute of Technology \\ Syracuse University \\ Urban Institute
}




\begin{abstract}
Many accounts of pension politics assign primary importance to societal forces. In the well-known formulation, pensions are the "third rail” of politics: politicians cannot cut benefits without suffering electoral retribution. In addition, some see the preferences of business as a key determinant of pension policy. This study takes aim at this problem by exploring what factors lead citizens and firms to support public pension systems and various reform efforts. To answer these questions, we analyze a survey of individuals and firms in 20 countries from five continents regarding attitudes toward pensions conducted by the Oxford Institute of Aging and the HSBC Bank. We examine separately variation in individual and then firm preferences regarding the role of government in pension provision and pension reform options. Then, we compare the preferences of firms to those of individuals to identify the potential space available for policy reform. The main results from the analyses are three. First, there are large cross-national differences in preferences of both individuals and firms. Second, these cross-national differences are not well explained by conventional theories. Third, there is some but not overwhelming support for micro-level theories about the reasons for differences between firms and individuals.
\end{abstract}




\section{Introduction}

Many accounts of pension politics assign primary importance to societal forces. In the well-known formulation, pensions are the "third rail” of politics: politicians cannot cut benefits without suffering electoral retribution. The reason is that pensions are popular. Even in the prototypical liberal welfare state of the U.S., support for public pension provision remains consistently high (Shapiro and Young 1989, Page and Shapiro 1992). Several theories also see the preferences of business as a key determinant of social welfare and pension policy. While it was once assumed that businesses opposed government provision of pensions, recent research has emphasized both the diverse interests of firms and the fact that they sometimes come to favor state responsibility.

What is still uncertain is the origin of these preferences. Why do certain individuals and firms come to support or oppose specific social policies? The question has become more important in recent years as countries introduce or consider radical reforms to their pension systems, including privatization. Existing theories have a difficult time explaining such changes. If citizens and sometimes firms support public provision of pensions, such changes should be difficult if not impossible. How then do such cut backs take place?

This study takes aim at this problem by exploring what factors lead citizens and firms to support public pension systems and various reform efforts. To answer these questions, we analyze a survey on attitudes about pensions conducted by the Oxford Institute of Aging and the HSBC Bank. The survey asked nationally representative samples of individuals and firms in 20 countries from five continents their views on the past and future of their country's pension system. The survey is unique in its cross-national scope and its inclusion of firms as well as individuals. (See Data appendix for a more detailed discussion of the surveys.)

We begin by examining separately variation in individual and then firm preferences regarding the role of government in pension provision and pension reform options. Then, we compare the preferences of firms to those of individuals to identify the potential space available for policy reform. The main results from the analyses are three. First, there are large crossnational differences in preferences of both individuals and firms. Second, these cross-national differences are not well explained by conventional theories. Third, there is some but not overwhelming support for micro-level theories about the reasons for differences between firms and individuals. 


\section{Individual preferences regarding pensions and pension reforms}

Explanations for public preferences have focused on both individual and national level factors. At the individual level, the main explanation for preferences is self-interest. Citizens are presumed to favor policies that will benefit them, making such policies popular among those likely to need government support. Thus, the unemployed, the aged, women, and the less welloff will tend to favor welfare programs because they are likely to avail themselves of these programs (Blekesaune 2007, Blekesaune and Quadagno 2003, Cook and Barrett 1992, Svallfors 1997). Iverson and Soskice (2001) argue in this tradition that the skill level of workers affects their preferences - workers with more specific skills face greater risks in the labor market and will therefore demand more social insurance.

National-level variables are also found to influence preferences. On the economic front, poor economic performance might lead all citizens to greater support for welfare policies regardless of their individual situation by creating general worries about risk. Meanwhile, more developed economies might increase confidence that the state will provide insurance against market risks. Considerable attention has also focused on the relation between existing welfare policies in a country and public support for the welfare state. The idea is that existing policies create specific expectations as well as structural reasons for preferring certain policies (cf. Svallfors 1997, Blekesaune 2007, Mehrtens 2004, Gelissen 2001, Arts and Gelissen 2001, Jaeger 2006, Linos and West 2003).

Most of these studies suffer from two shortcomings. One is their focus on a relatively limited number of countries, mainly in Western Europe (though see Lipsmeyer and Nordstrom 2003, Lipsmeyer 2003, Gough 2000). Because of the relative similarity of these countries, there is a problem of selection bias. In particular, less developed countries have been excluded from most studies and there are good reasons to believe that their citizens have different preferences. For example, one strand of research proposes that family plays a large role in social provision in these countries (Gough 2000).

Another shortcoming is the focus on general opinions regarding redistribution or welfare. ${ }^{1}$ The main dependent variables in these studies are either opinions on redistribution (should the government make incomes more equal) or aggregated responses to questions on government responsibility for a variety of specific policies. The problem with considering such

\footnotetext{
${ }^{1}$ For an exception see Boeri, Börsch-Supan, and Tabellini (2001).
} 
general opinions is that they are not obviously linked to specific policy choices. Governments make policy in specific areas and the details of these policies often matter. Citizens have different views on pensions, healthcare, and unemployment insurance (Lipsmeyer 2003). Moreover, studies of how politicians use public opinion find that they are splitters rather than lumpers (Druckman and Jacobs 2006). That is, politicians look at opinions on specific policies rather than the general ideological mood. Our work tries to overcome these problems by looking at a wide range of countries and opinions on a specific policy area.

\subsection{Evidence from individual surveys of attitudes toward pensions and pension reform}

Our data suggest significant variation in pension preferences among individuals in different countries. Figure 1 illustrates individuals' beliefs regarding who should finance their pension and who will finance their pension in the ten countries where these questions were asked. Individual beliefs regarding who should pay for retirement vary significantly between countries. Contrary to the logic of industrialism, developed economies do not consistently have higher levels of support for government provision of support in old age $(r=0.031, p=0.933, n=$ 10).

Instead, countries with historically more extensive or social democratic welfare institutions, including Sweden, Poland and Russia, are those where the greatest proportion of individuals believe the state should be the primary provider of old age welfare. Also consistent with the coincidence between welfare regime type and preferences, respondents in the only conservative welfare regime in this reduced sample, Germany, believe individuals rather than government should bear the financial burden of retirement. Only in the Middle East and Southeast Asia do individuals believe workers and their families should have primary responsibility for old age welfare. In Southeast Asia, this pattern is consistent with characterizations of Southeast Asian welfare regimes as being heavily dependent on family provision of welfare (Gough 2000). Though preferences tend to co-vary with general patterns of welfare, it is unclear whether preferences explain the welfare institutions or institutional legacies shape preferences. 
Figure 1: Who should and will bear the costs of retirement?
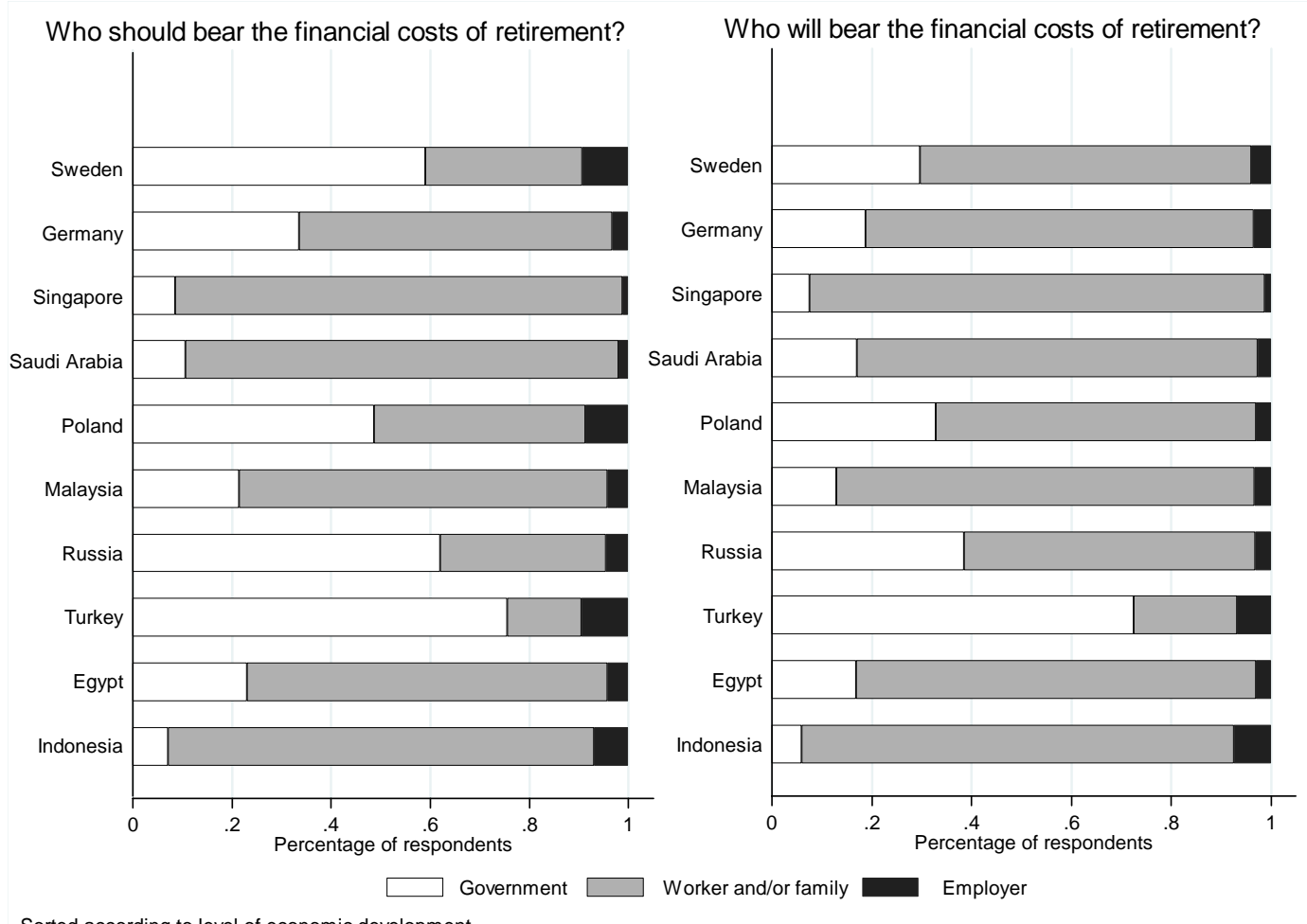

Figure 1 also illustrates the differences in beliefs about who should and who will provide old age income. In all countries except Saudi Arabia, individuals believe that both government and employers will provide less retirement support than they should. The size of the confidence gap —or the difference in the proportion believing the government should finance retirement and the proportion believing government will finance retirement-is statistically significant in almost all countries (see difference of proportion tests in Table 1). Interestingly, the difference between expectations that the government should finance retirement and that the government will actually finance retirement appear greatest in countries with higher levels of economic development and more developed welfare institutions, such as Sweden, Poland, Russia, and to some extent Germany.

Figure 2 depicts the confidence gap between the proportion of individuals that feel the government should and will finance retirement. The gap, reflected in the distance of the country point from the 45 degree line, is largest in countries that have historically had the most extensive welfare regimes, suggesting that more generous or universal welfare regimes are more likely to fall short of individual expectations. Most individuals feel the costs of retirement not paid by the 
government will be borne by them or their families. Families are expected most often to bear the costs of retirement in Asian countries, which are characterized as relying on families for welfare provision. Again, this suggests that cross-national preferences coincide with existing welfare institutions.

Figure 2: Individual confidence gap for government responsibility

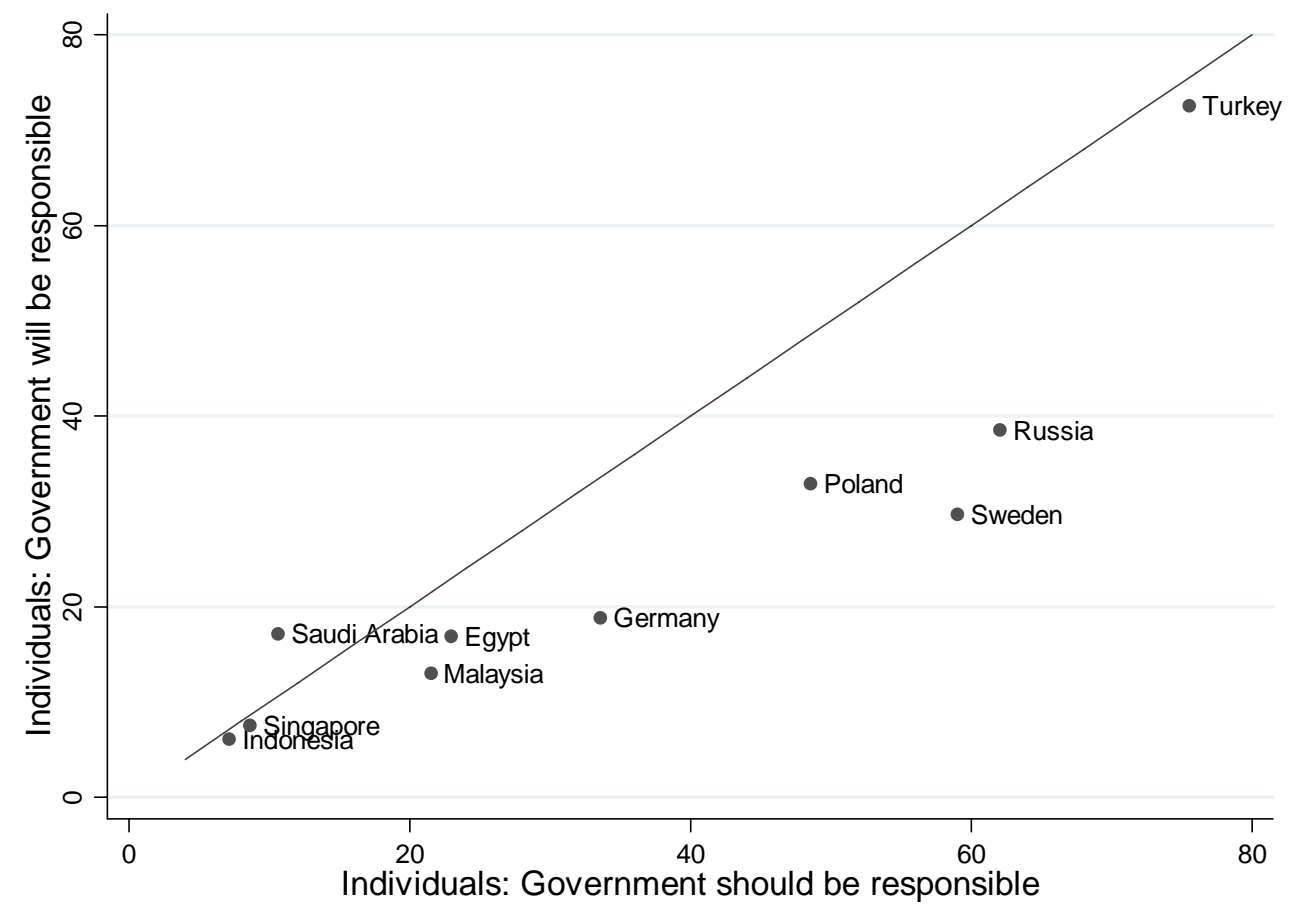

Though most individuals perceive that government pensions will not provide sufficient old age income, they do not necessarily agree on the ways to address the challenges faced by the existing pension system. In response to a question about preferences regarding pension reform, individuals again reflect the heterogeneity of preferences within and between countries. ${ }^{2}$ Figure 3 graphs the preferences among four reform options: enforcing additional private savings, raising the retirement age, increasing taxes, or reducing pension amounts. Though these options do not represent the full menu of reform options available to governments with public pension systems, they provide a limited window into support for different reform options.

\footnotetext{
${ }^{2}$ The question reads, "As the number of old people increases substantially, governments might need to make difficult economic choices. If that occurs, which one of the following do you think the government in this country should do first in supporting and financing an aging population?”
} 
Figure 3: What should the government do first in supporting and financing an aging population?

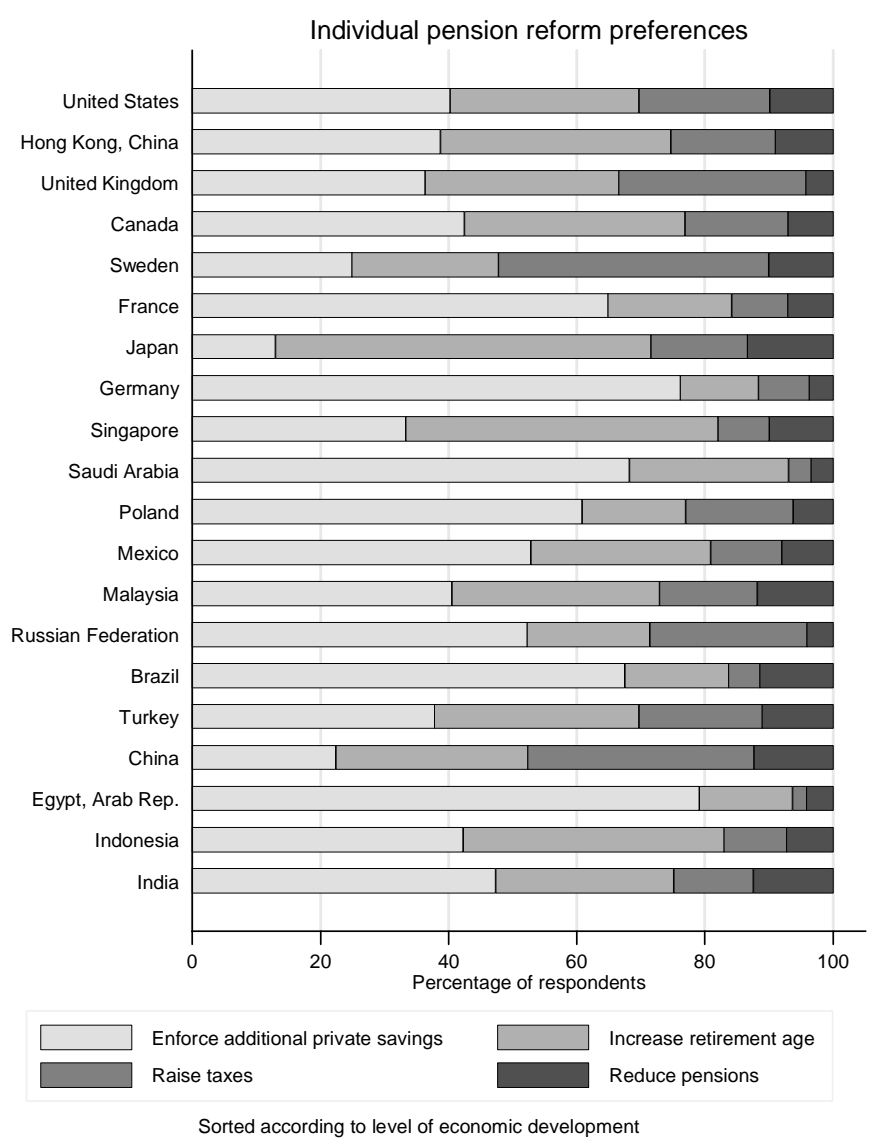

Perhaps most surprising in the figure is the widespread support for enforcing additional private saving, particularly in non-Asian countries, though this could be an artifact of the options provided and the lack of tradeoffs. At the same time, in some cases, like Russia, the support for mandatory private saving is inconsistent with the belief that government should shoulder the responsibility for retirement illustrated in Figure 1. In such instances, support for increased mandatory savings may reflect distrust of the public pension system, or the inability of public pensions to match the level of support they should, as much as an embrace of individual private savings. In other cases, patterns are more consistent with expectations and answers to other questions in the survey. For instance, respondents in Sweden support raising taxes and also believe the government should bear the costs of retirement. In contrast, Germans both believe workers should finance their retirement and strongly support enforcement of additional private savings to ensure old age incomes.

The relationship between public preferences and existing welfare institutions can also be explored in retirement ages. In nearly all countries in the sample, the difference between the 
legal retirement age for men and women in the main public pension system is significantly different from the age at which people believe men and women should retire (see Table 1 for difference of means tests). Like the between-country variation observed in preferences regarding pension reforms, there is significant between-country variations in the average age at which people believe men and women should retire. ${ }^{3}$ In all countries except Saudi Arabia, however, people believe that the ideal retirement age for women is significantly lower than that for men. ${ }^{4}$

The proportion of citizens who prefer raising taxes among the four reform options may also be shaped by the existing distribution of contributions for public pension schemes in each country. For instance, in countries with higher worker contribution rates, we might expect support for further increases in taxes to support pensions to be low. Indeed, the correlation between the public pension scheme average worker contribution rate and the proportion of individuals who prefer raising taxes is negative, though not statistically significant $(r=-0.363$, $p$ $=0.116, \mathrm{n}=20$ ). There is no correlation between the employer contribution rate and individual preferences for raising taxes $(0.170, \mathrm{p}=.473, \mathrm{n}=20)$. Together, the preceding discussion of cross-national patterns in beliefs about who should and who will bear the costs of retirement and preferences among reform options for the public pension system illustrate the ways in which existing institutions vary with cross-national differences in public opinions.

Are there any microlevel determinants of preferences? Table 2 presents multivariate regression results for each country where we consider the relationships between preferences for pension reforms and income, gender, age, and employment status. ${ }^{5}$ Reform preferences are modeled using multinomial logistic regression in each country. Because the question wording does not encompass all available reform options and leaves the option of private savings open to various interpretations, the results should be interpreted with caution.

Rather than discuss the statistical significance of each variable in each case, it is perhaps more instructive to discuss the patterns of significance and insignificance. For example, gender does not appear to be a significant predictor of attitudes toward pension reform options, except in Brazil, Canada, and Saudi Arabia. In most countries, age increases the probability that someone will support raising taxes or the retirement age rather than enforcing additional private saving

\footnotetext{
${ }^{3}$ One-way ANOVA for men's retirement age: $F=213.96,19 \mathrm{df}$, and women: $\mathrm{F}=335.55,19 \mathrm{df}$.

${ }^{4}$ Based on difference of means tests.
} 
and will be more likely to support enforced private saving than reducing pensions, though the effects are seldom statistically significant. Though employment status does not have a significant effect on pension reform preferences in many countries, where employment status matters, its impact on preferences is usually consistent with expectations. Further, though the individual dummies for employment status are usually not statistically significant, jointly the variables for employment status are significant.

The effect of employment status and income on pension reform preferences is heterogeneous across countries. For example, the patterns of preferences in Canada, the United Kingdom, and the United States are very similar. Income increases the probability that an individual will prefer enforcing additional private savings. Interestingly, income also has a small positive effect on the probability of preferring an increase in taxes as well. At the same time, income in these liberal welfare regimes reduces the probability of preferring a higher retirement age or lower pension amounts, though the effects are not pronounced. In conservative or Christian Democratic welfare regimes, France and Germany, the effects of income on pension reform preferences differ markedly from those in the liberal welfare regimes. Higher incomes actually reduce the probability that an individual will prefer enforcing additional private savings or raising taxes. In those two countries, income increases the probability that an individual will prefer increasing the retirement age.

Not unlike the advanced industrialized countries, the effects of employment and income on reform preferences are also heterogeneous in the developing world. For example, income increases the probability of supporting private savings and reduces the probability of supporting an increase in the retirement age in both Mexico and Brazil. At the same time, income has little effect on the probability of supporting reduced pensions or increased taxes in either of those countries. In Singapore, China, and Hong Kong, income has a similar effect to that observed in Mexico and Brazil. However, in those countries, income is also associated with increased probabilities of supporting an increase in taxes or reduced probabilities of supporting reduced pensions. At the same time, the effects of income on pension reform preferences in Poland and Russia differ, especially with regard to the probability of preferring an increase in the retirement age or enforcing additional private savings.

\footnotetext{
${ }^{5}$ In the models, age is measured in 10 year increments, and income is measured in 10 to 13 income brackets, which makes direct comparison of coefficients across countries problematic. Employment status includes dummy variables for full-time, part-time, unemployed, student, retired, and homemaker categories.
} 
This overview of the results of the models of pension reform preferences is consistent with observations that pension preferences are likely to be shaped not only by individual level characteristics but also to vary systematically between countries with different levels of economic development and existing welfare institutions. In addition, the effects of individual level characteristics on preferences also appear to vary between countries.

Overall, our analysis of the surveys of individuals in this 20 country sample suggests the following observations regarding public opinion and pensions:

1. There is a gap between beliefs that government should provide old age support and the likelihood that it will.

2. Many of the hypotheses related to individual characteristics and welfare preferences may not provide useful generalizations beyond advanced industrialized democracies. Skill level and income, for instance, do not often have the effects on preferences predicted by the literature.

3. Likewise, theories that are useful for explaining attitudes toward redistribution or support for welfare or social insurance in general may not provide sufficient insight into the opinions that drive policy preferences for public pension policy.

4. The cross-national comparisons of both aggregate opinions and patterns observed in the regression analysis suggest that public opinions tend to coincide or vary with existing welfare regimes or pension institutions.

\section{Firm preferences regarding pensions and pension reforms}

One of the seminal advances in social policy research in the last ten years has been the explicit attention paid to the role of firms. Earlier research had largely taken the position of firms for granted. They were assumed to universally favor market provision of most social services and oppose expansion of the welfare state. As Martin (1995) put it, the conventional wisdom was that the preferences of firms could be read off their material position and that firms only impede progress. Recent research challenges this conception, emphasizing both the central role of firms and the heterogeneity of their preferences. Swenson (2002) has pioneered the proposition that the preferences of firms cannot be taken for granted.

Recent work by Mares (2003) argues that firms differ according to their utility for risk and their utility for control. Firms with high risk - because of volatility in demand for their products, the possibility of workplace accidents, or an aging workforce - would prefer to expand the risk pool for social policies to hedge these risks and would support state provision. Firms with highly skilled workers and a larger workforce would prefer in-house provision of social services because they could exercise greater control over their workers at reduced cost. She finds such preferences characterized major firms in France and Germany on policies like workers 
compensation, unemployment insurance, and early retirement. Another school of thought has argued that a country's position in the global economy might affect the preferences of its firms (Katzenstein 1985). Firms in countries less shielded from the global economy might come to favor state provision because they can not offer such benefits themselves.

While existing works have found support for these hypotheses, what is missing are tests that use a large sample of firms in a given country and compare a diverse group of countries. Most studies have looked at only a single country or a small group of countries and have relied on qualitative evidence or a small number of firms. The survey that we analyze allows us to consider a large number of firms and countries.

\subsection{Evidence from individual surveys of attitudes toward pensions and pension reform}

In this section, we investigate the nature and causes of firm preferences. Figure 4 presents responses to the question, “As a company, who do you believe should bear most of the financial costs of supporting employees in retirement?” The first thing to note is that not all firms oppose government responsibility for pensions. In fact, of the 5,642 firms, government responsibility was the most popular choice of 2,579 or $46 \%$, followed by employee responsibility $(1,686$ or $30 \%$ ), employer responsibility (1,013 or 18\%), and family responsibility (364 or 6\%). Indeed, government responsibility was the most popular choice in 11 of 20 countries including both democratic ones (Brazil, France, Mexico, Poland, Sweden, Turkey, and UK) and non-democratic ones (China, Egypt, Russia, and Saudi Arabia). Not surprisingly, employer responsibility was the least popular choice.

A second noteworthy fact is that there are significant differences between countries. What Swenson (2002) calls the equivalency premise is clearly not supported by these data. Firms hold a variety of preferences on who should hold responsibility for employees' retirements. These differences are clear in Figure 4. Countries cover almost the entire range of values from Brazil where over $80 \%$ of firms support government provision to India where less than $10 \%$ support government provision. 
Figure 4: Who should and will bear responsibility for retirement?

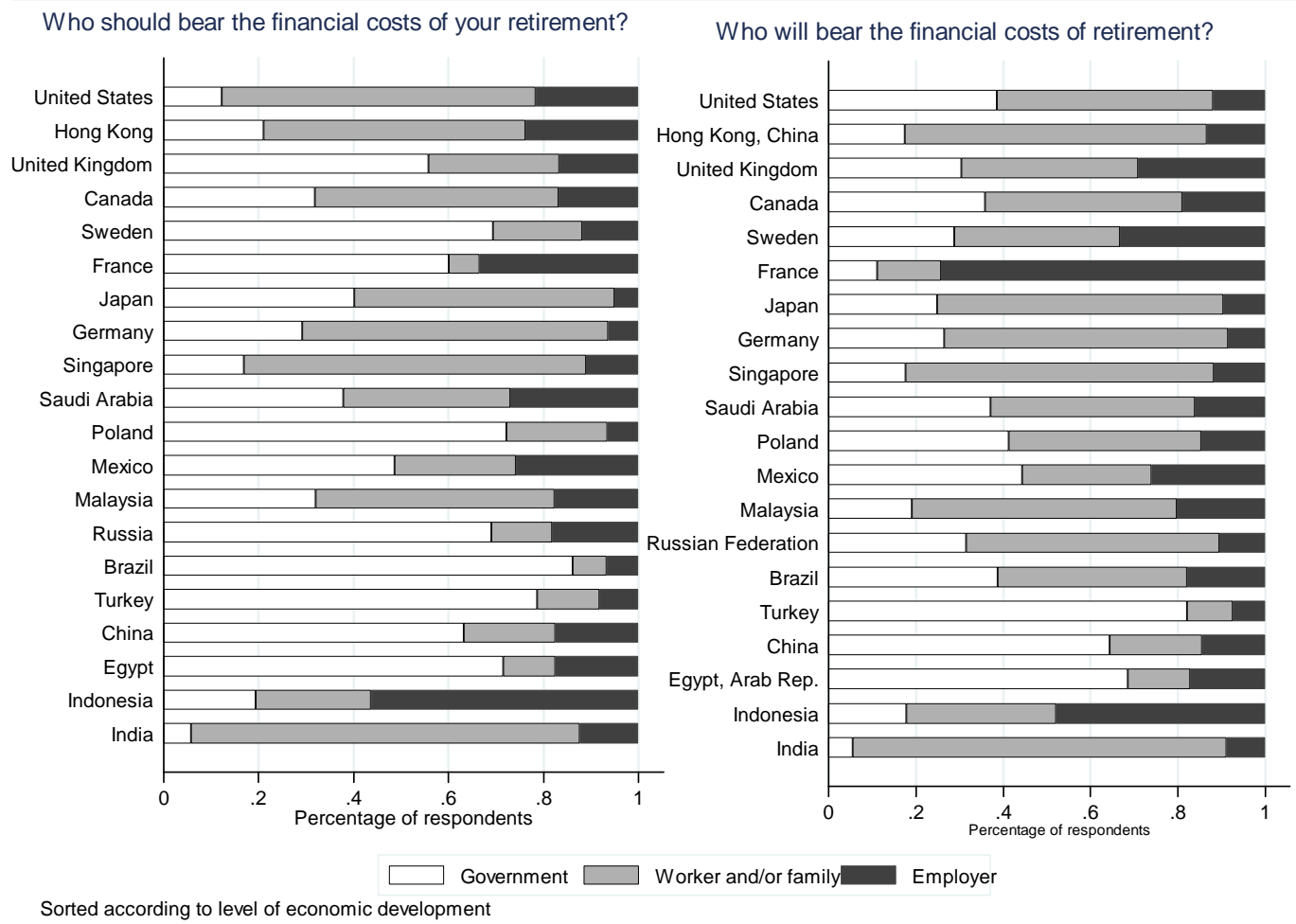

Can we explain these large cross-national differences? Few of the expected correlates of support for government responsibility are significantly related to attitudes. One might expect firms in richer countries to support government provision as the logic of industrialism would suggest, but in fact the correlation between support for government responsibility and GDP per capita is negative and insignificant $(r=-.36, \mathrm{p}=.12)$. Figure 5 plots support for government pension provision by level of economic development. The figure illustrates the lack of linear relationship but also a tendency for countries with similar historical trajectories or existing pension institutions to cluster. 
Figure 5: Firm support for government pension provision by level of development

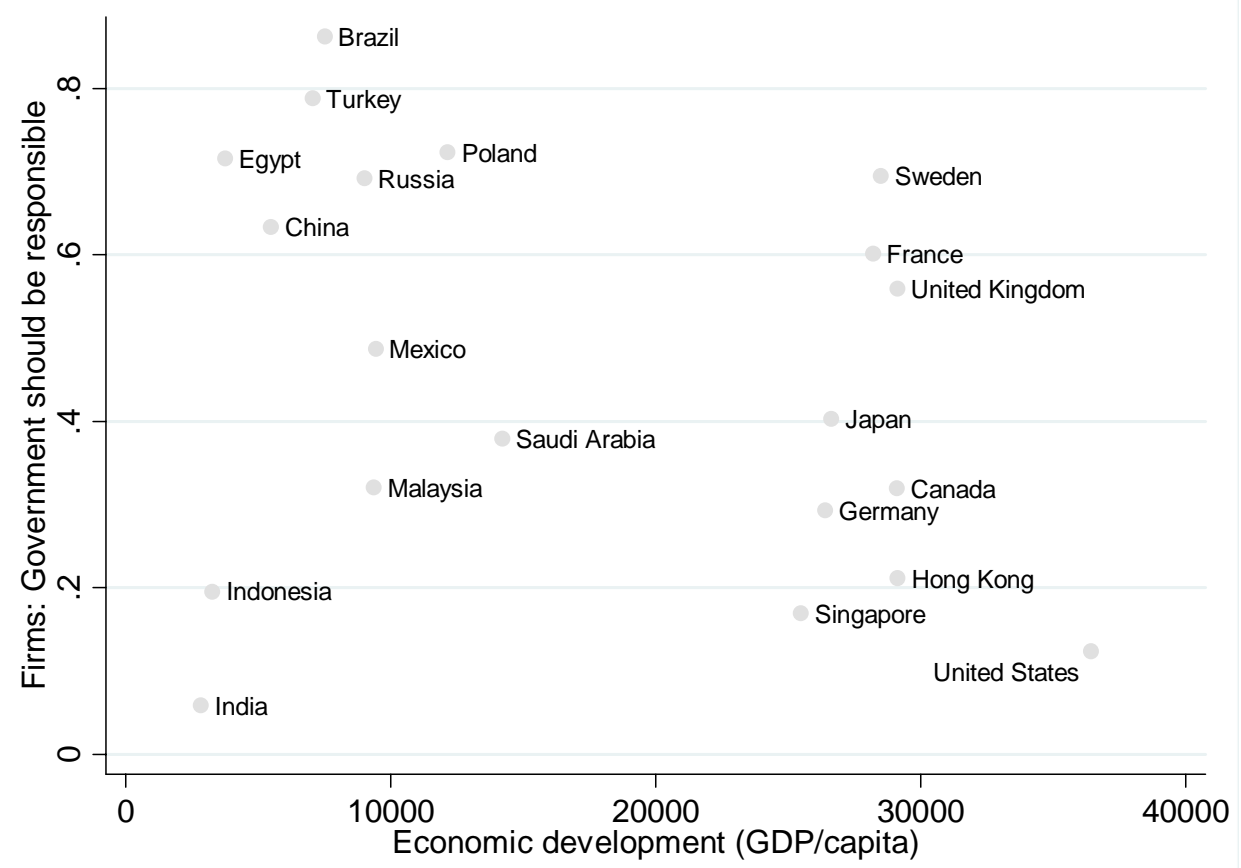

Another possibility is that firms have more positive attitudes towards government responsibility in countries where the state plays a large role in the economy. Government spending might be seen as a (weak) proxy for the liberal market versus coordinated market divide. But the correlation between government spending as a percentage of GDP and firm support is weak ( $\mathrm{r}=.12, \mathrm{p}=.56)$. If we look at just established democracies, we see that two liberal market economies (Canada and the US) and two coordinated economies (France and Sweden) fit expectations, but two other countries are reversed. Coordinated market economy Germany looks more like the US and Canada, while the UK approximates the coordinated economies.

Integration into the world economy might be expected to affect firms' attitudes. They may become more favorable to state intervention as Katzenstein (1985) argues or less because of competitive pressures caused by globalization. In fact, there is only a weak correlation between the ratio of imports plus exports to GDP and support for government responsibility ( $\mathrm{r}=.11$, $\mathrm{p}=.68)$.

Two other questions asked in the survey are also worth considering. The survey asked not only who should be responsible for retirement, but who will be responsible. The answers to this question are also shown in Figure 5. Here we see somewhat lower percentages who choose the government (34\% versus 46\% for should) and higher percentages for employees (33\% versus 
$30 \%$ ), employers (21\% versus 18\%) and the employee’s family (13\% versus 6\%). Figure 6 presents a scatterplot of country averages for the "should" and "will” questions. What is noteworthy here is that there is a strong correlation between answers to the two questions ( $\mathrm{r}=.61$, $\mathrm{p}<.01)$. Democracy seems to be working in the sense that firms expect to get what they want. Similarly noteworthy are the countries with the largest differences between "should" and "will", which we might refer to as a confidence gap. In particular, most of the countries with large differences are the developed democratic countries. Thus, US firms expect the government to be far more involved than they wish, while French and Swedish firms (along with those in the UK, Russia, Poland, and Brazil) expect much less involvement than they wish. This is surprising as one might expect these confidence gaps to be larger in less developed and less democratic countries. The fact that more countries are below a 45 degree line indicates that firms generally believe that governments will do less than they should. In nearly half the countries, the difference between the proportions of firms that believe the government should be responsible and would be response was statistically significant.

Figure 6: Who should and will be responsible for retirement

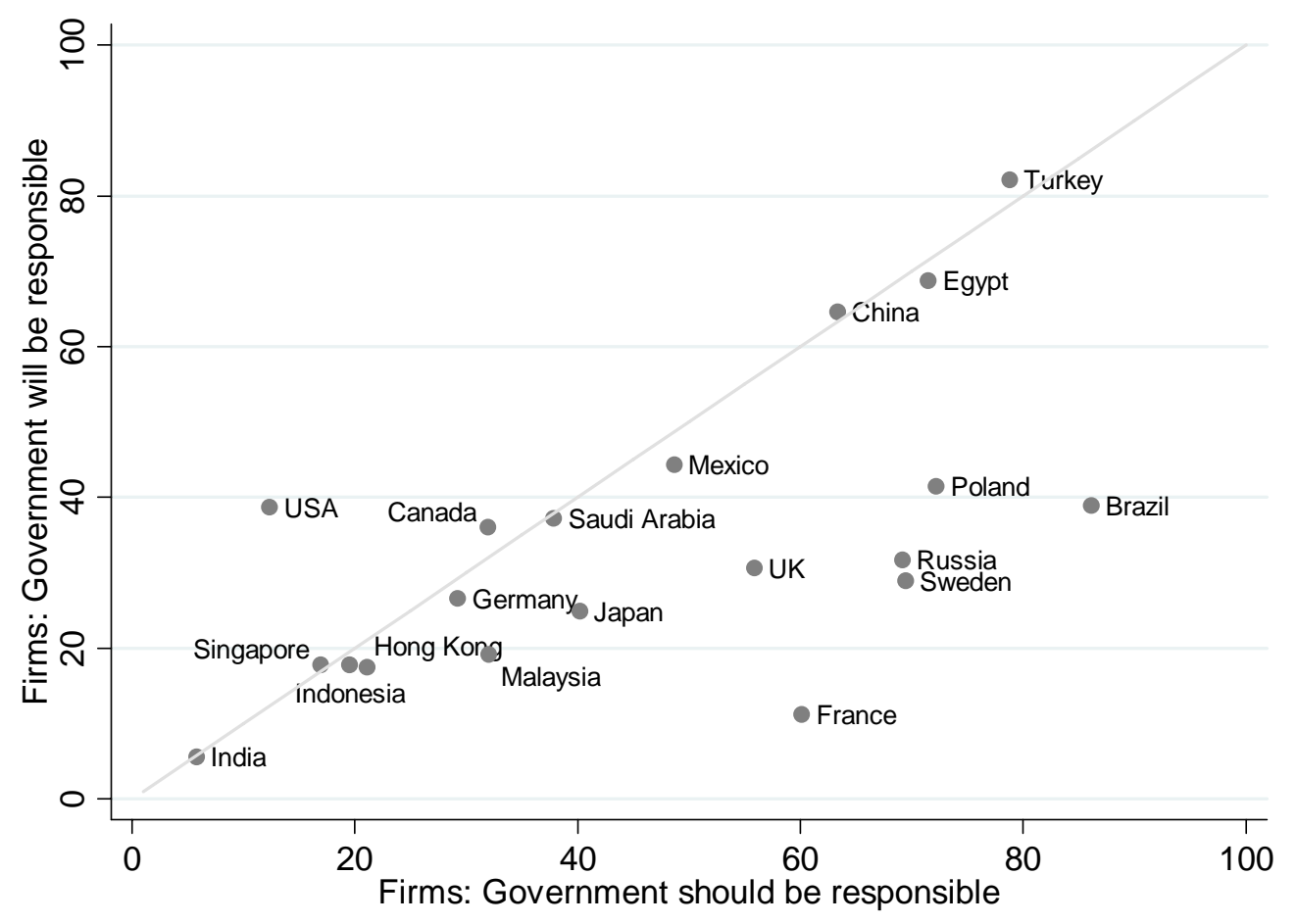


A final question worthy of interest asks firms how the government should respond to coming economic difficulties with the pension system. They could choose between four options: "reduce pensions," "raise taxes," "increase retirement age," and "enforce additional private saving.” Figure 7 presents the results. Not surprisingly 52.3\% of firms believed the government should enforce private savings. $27.5 \%$ chose increase the retirement age, $13.5 \%$ chose raise taxes, and $6.7 \%$ chose reduce pensions.

Figure 7: What should the government do to respond?

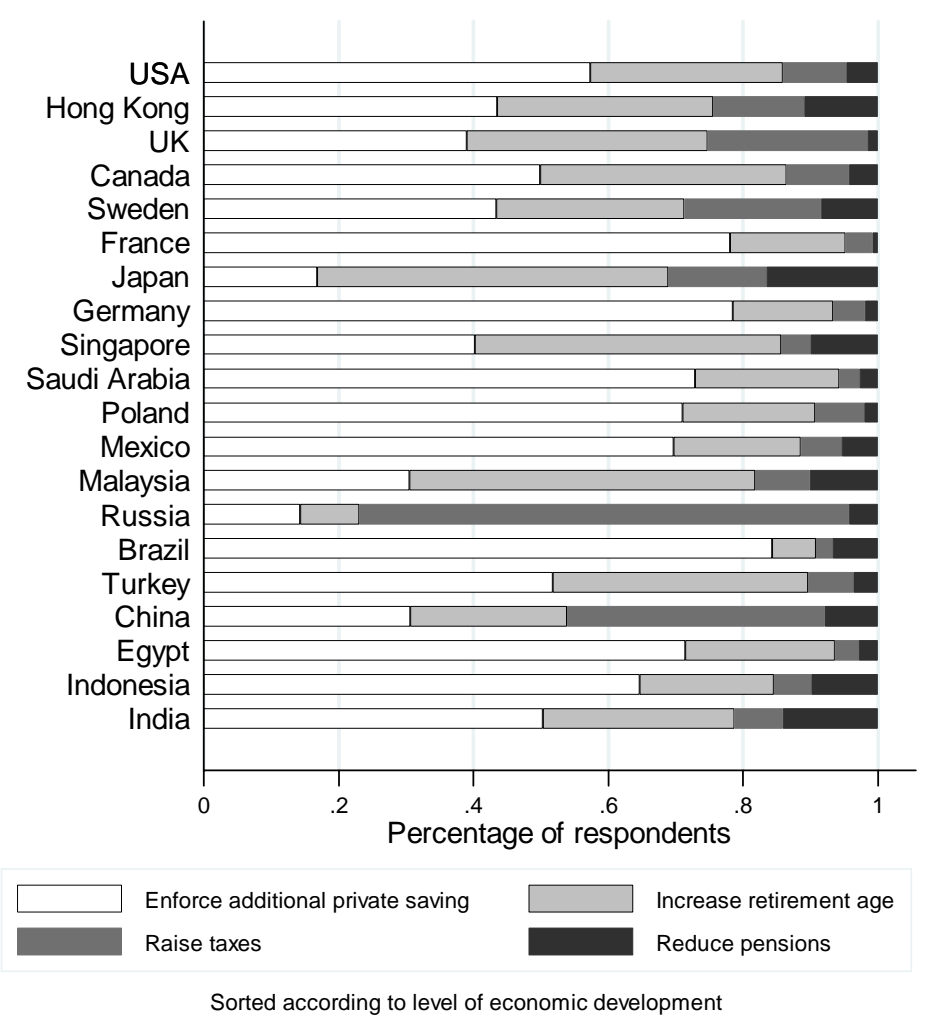

We turn now to the level of individual firms. What explains why firms have different preferences? We focus here on the question of who firms think should be responsible for retirement and in particular on reasons why firms choose government to be the responsible party. We look in particular at several different explanations for firm preferences for pension reform options. First, larger firms should favor mandatory private savings over less popular alternatives, like raising taxes or the retirement age, because large firms are more likely to be able to internalize the costs of pension provision. Size is measured by number of employees (fewer than 
99, fewer than 500, or more than 500) and country-specific revenue categories (10-14 categories for each country. ${ }^{6}$ Second, we expect firm preferences to vary according to sector of the economy. Firms in secondary (i.e., manufacturing) and tertiary (e.g., services, retail/wholesale trade) sectors should favor government provision, thus be less likely to support mandatory private savings. Finally, we consider whether foreign ownership affects preferences, again using a dummy variable.

Table 3 presents the results of multinomial logistic regressions of firm preferences for pension reforms on these independent variables. The results are mixed and usually inconsistent with expectations. Size and revenue were not usually significant predictors of opinions. Sector is often the only variable that has a significant effect on reform preferences, though the effects are inconsistent with both theory and across countries. Unfortunately, the reduced sample sizes for the relevant policy questions preclude multilevel or hierarchical analyses. In large part, these weak results derive from the heterogeneity across countries in the preferences of different types of firms for different reform options.

To summarize the firm results, we found that:

1. There are large country differences in firm preferences with many firms supporting state responsibility for pensions.

2. These country differences are not well explained by standard theories, though more work needs to be done here.

3. There is something of a confidence gap between firms' preferences of who should be and who will be responsible for pensions with most firms expecting that the government will not fulfill its proper role.

4. When asked to choose among reform options, firms by a large margin prefer expanding private savings over making cuts in the existing system.

5. Micro-level theories of firm reform preferences should probably condition for the economic context in which firms operate, in terms of level of development and trade openness at a minimum. More work needs to be done in this regard, though the present surveys provide insufficient data for detailed analyses.

\section{The intersection of individual and firm preferences regarding pensions and pension reforms}

In this section, we juxtapose the firm and individual preferences. Most theories would predict considerable differences between these groups. Theories premised on class conflict expect individuals in a given country to be more favorable to government responsibility than firms. A new generation of theories going under the label "varieties of capitalism”, however,

\footnotetext{
${ }^{6}$ The survey did not report the exact number of employees and exact revenue, but only three classes.
} 
expect larger cross-national differences. They argue that conflict is not so stark and social policy can be explained by class coalitions rather than conflicts

Figure 8 presents a scatterplot of country averages on the question of whether the government should bear responsibility for retirement. There appears to be a strong correlation between the preferences of firms and individuals $(r=0.814, p=0.004)$ with only Egypt and Saudi Arabia standing as outliers. This suggests that there are important national level factors that affect both firms and citizens and that class conflict is relatively weak. A surprising result of this comparison is that employers are more likely to favor government responsibility than employees. It may be due to greater knowledge of the effects of different systems among firms or a stronger preference for employer and family responsibility among citizens. In any case, the results gave greater support to the Varieties of Capitalism approach - national differences are larger than class differences.

Figure 8: Public and firm attitudes about who should finance retirement

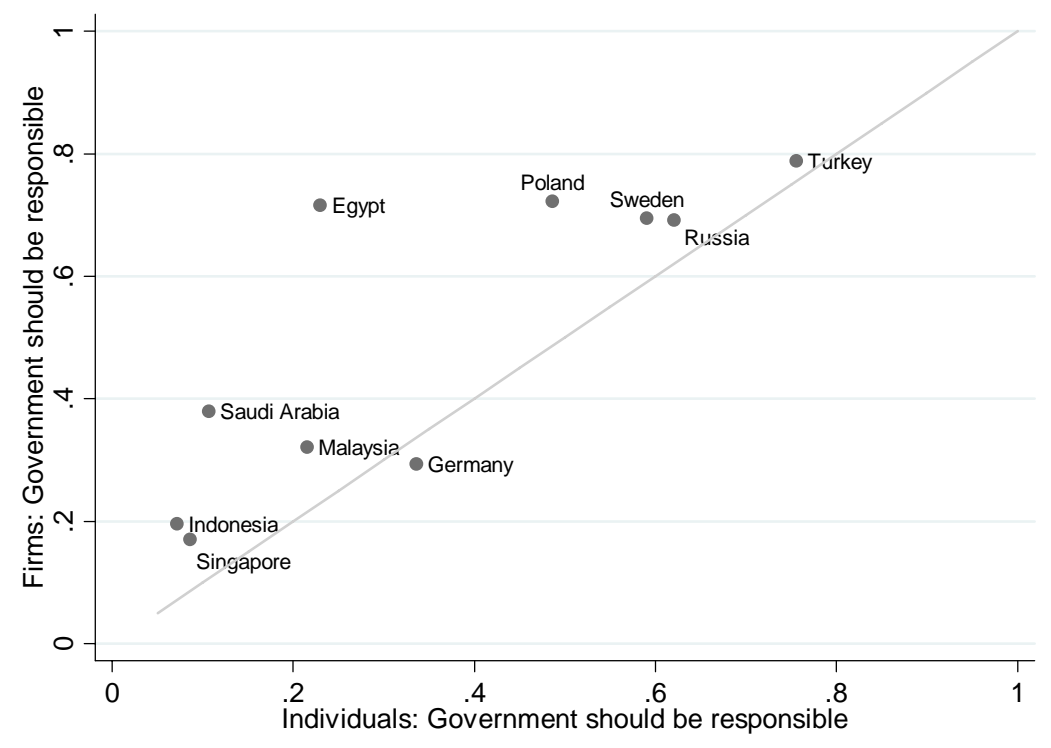

Attitudes regarding the four reform options included in both surveys help illustrate areas of consensus and divergence between firm and public attitudes regarding pension reform. Figure 9 shows that firms tend to express greater support than citizens for additional private savings which might be expected given the greater openness of businesses to market solutions. Nevertheless, this solution is still quite popular among employees, suggesting potential for additional privatization around the world. 
Figure 9: Public and firm preferences for enforcing additional private savings

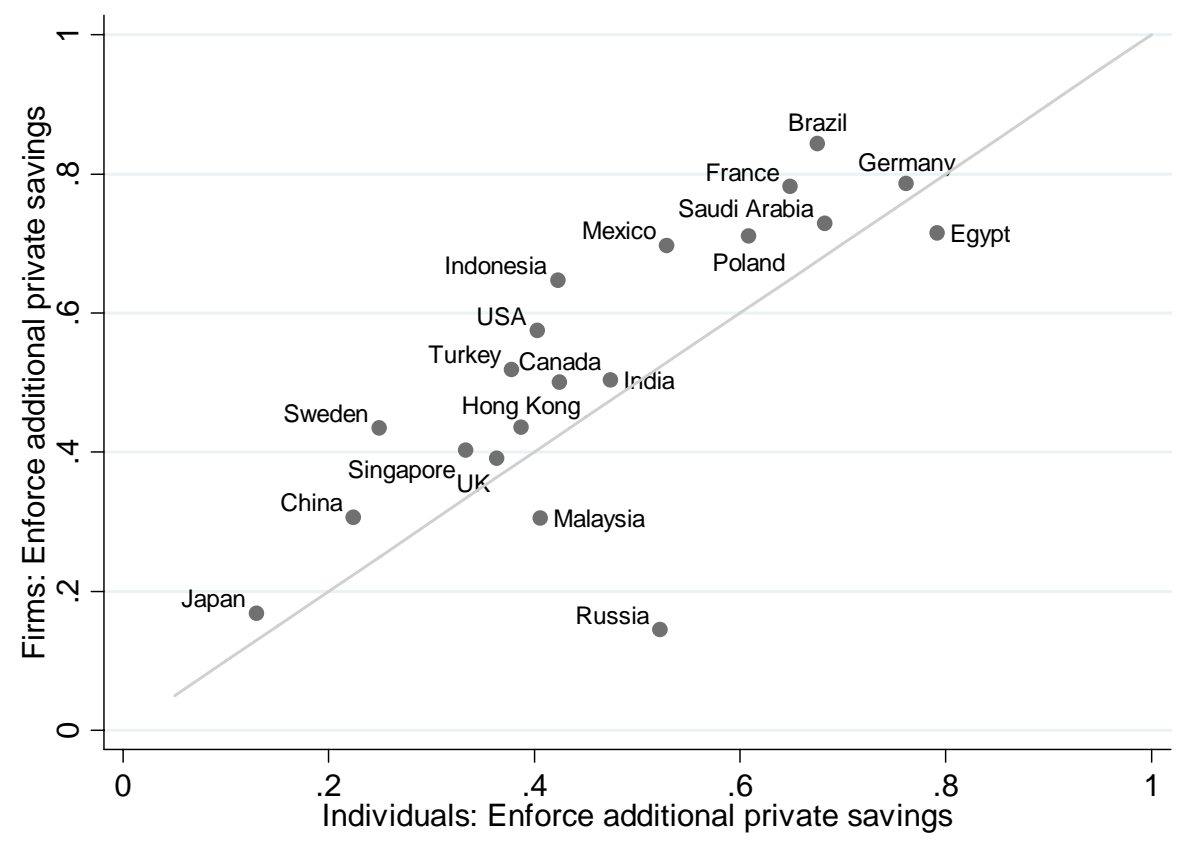

On policies that involve cutbacks, we see that workers are also more likely to support reducing pensions and increasing the retirement age (Figures 10 and 11). One would have expected firms to be more in favor of these latter two options. Noteworthy are the reasonably high levels of support for increasing the retirement age among workers in many countries and at the same time little support for reducing pensions either among firms or workers. The ways in which preferences between the public and firms tend to coincide is again notable. ${ }^{7}$ There are strong correlations between workers and firms for all four reform options. The consistency of these attitudes between the public and firms again suggest that national level factors may be important.

\footnotetext{
${ }^{7}$ Only in Russia do firm and public preferences appear to differ significantly.
} 
Figure 10: Public and firm preferences for reducing pensions

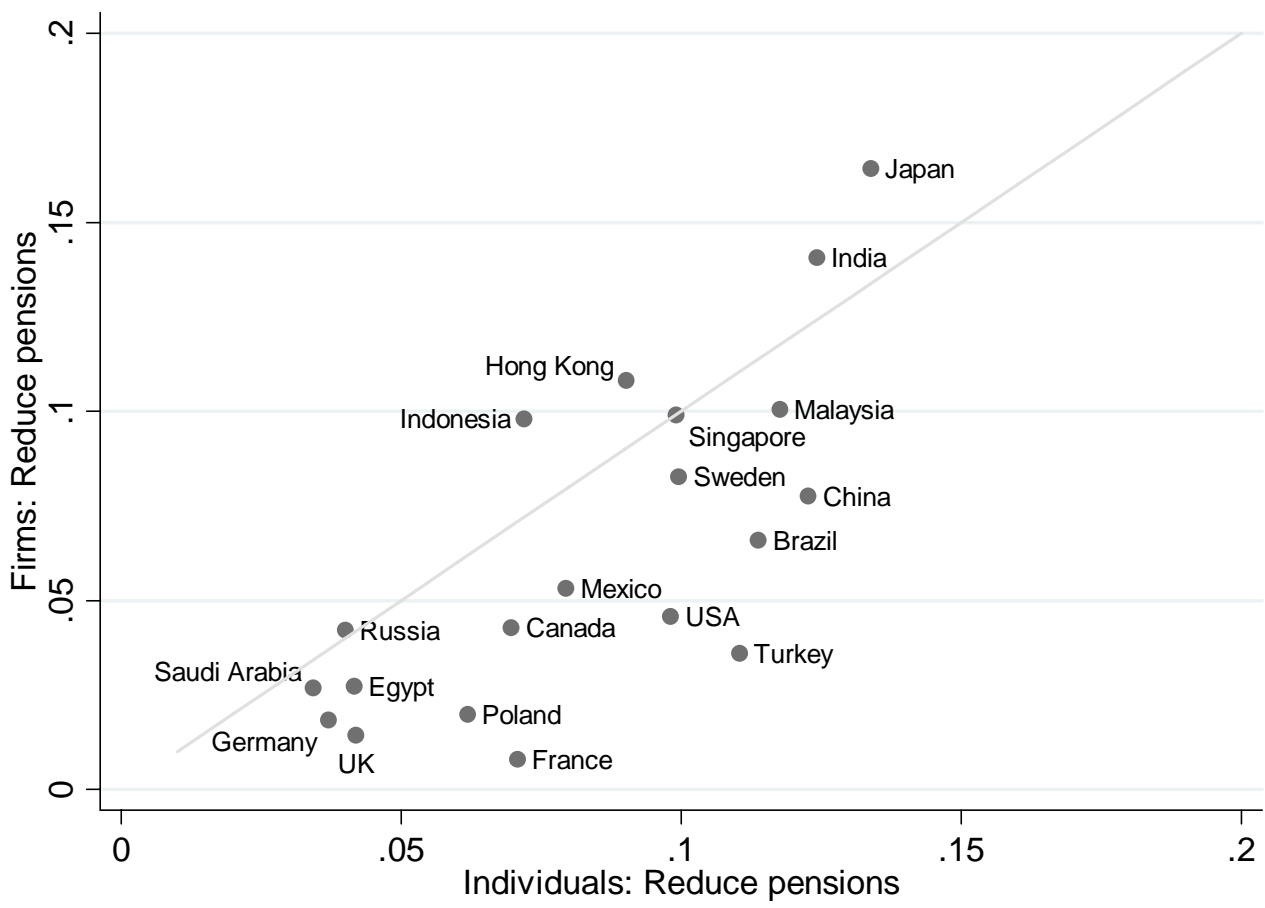

Figure 11: Public and firm preferences for increasing retirement age

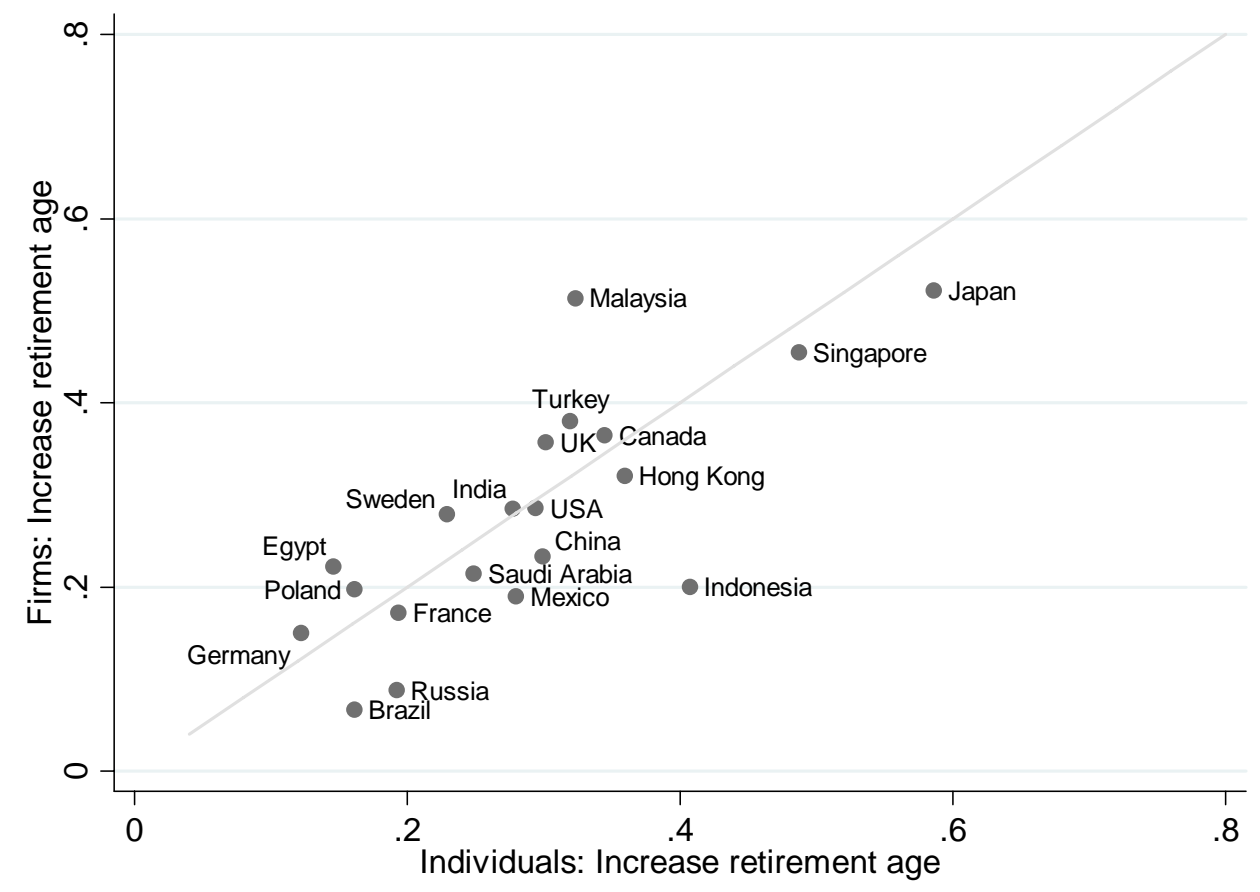




\section{Summary}

The results are in many ways surprising. At both the individual and firm levels there appear to be large differences in attitudes towards pensions across countries. By contrast, within countries we had relatively little success in explaining individual-level and firm-level differences. Perhaps most surprising was that firms and individuals tended to have similar attitudes within countries but not across countries. There appear to be distinctive country-level attitudes and relatively little evidence of class conflict.

This result has two important policy implications. One is that pension reform may not be an insurmountable hurdle in most countries. Insofar as individuals and firms share attitudes, they should be able to arrive at mutually beneficial agreements on the proper reforms. The old days of class conflict may be behind us at least on the issue of pensions. In many cases, in fact, firms were more supportive of state pensions than individuals and both tended to believe that the government should do more than it will.

On the other hand, the form of these reforms should differ significantly across countries. The large differences between countries on questions of responsibility and types of reform imply that they will choose very different reforms. It would be a mistake to assume that one-size-fits-all in the area of pension policy. This result supports the varieties of capitalism view that there are nationally-distinctive production regimes which require different sorts of social policies.

As far as specific reforms go, there appears to be fairly widespread support for additional private savings across firms and individuals. Both would prefer to avoid "hard" cuts in pension systems and instead carve out new private accounts. While such private accounts are not a solution to the problems facing these countries unless combined with other expenditure reductions, they can be (and are) often packaged as part of a solution. These preferences may in fact be a heretofore ignored cause of the spread of pension privatization around the world.

\section{References}

Arts, W. and Gelissen J. 2001. Welfare States, Solidarity and Justice Pirnciples: Does the Type Really Matter?” Acta Sociologica 44: 283-299.

Blekesaune, Morten and Jill Quadagno. 2003. "Public Attitudes toward Welfare State Policies: A Comparative Analysis of 24 Nations.” European Sociological Review 19:415-427.

Blekesaune, Morten. 2006. "Economic Conditions and Public Attitudes Toward Welfare State Policies.” ISER Working Paper 2006-45. Colchester: University of Essex.

Boeri, Tito, Axel Börsch-Supan, and Guido Tabellini. 2001. "Would you like to shrink the welfare state? A survey of European citizens.” Economic Policy 16: 7-50. 
Druckman, James N. and Lawrence R. Jacobs. 2006. "Lumpers and Splitters: The Public Information that Politicians Collect and Use.” Public Opinion Quarterly 70: 453-476.

Gelissen, John. 2001. "Old-age Pensions: Individual or Collective Responsibility? An Investigation of Public Opinion Across European Welfare States." European Societies 3: 495-523.

Gough, Ian. 2000. Welfare Regimes in East Asia and Europe: Comparisons and Lessons. Presented at Towards the new social policy agenda in East Asia, Parallel session to the Annual World Bank Conference on Development Economics, Europe, Paris, 27 June.

Iversen, Torben and David Soskice. 2001. "An Asset Theory of Social Policy Preferences." American Political Science Review 95: 875-893.

Linos, K and M. West. 2003. "Self-Interest, Social Beliefs, and Attitudes to Redistribution: Readdressing the Issue of Cross-National Variation.” European Sociological Review 19: 393-409.

Lipsmeyer, Christine S. 2003. "Welfare and the Discriminating Public: Evaluating Entitlement Attitudes in Post-Communist Europe.” The Policy Studies Journal 31: 545-564.

Lipsmeyer, Christine S. and Timothy Nordstrom. 2003. "East Versus West: Comparing Political Attitudes and Welfare Preferences Across European Societies.” Journal of European Public Policy 10: 339-364.

Mares, Isabela. 2003. The Politics of Social Risk: Business and Welfare State Development. New York: Cambridge UP.

Martin, Cathie Jo. 1995. "Nature or Nuture? Sources of Firm Preference for National Health Reform.” American Political Science Review 89: 898-913.

Mehrtens, F. John, III. 2004. "Three Worlds of Public Opinion? Values, Variation, and the Effects on Social Policy.” International Journal of Public Opinion Research 16: 115-143.

Meier Jæger, Mads. 2006. "Welfare Regimes and Attitudes Toward Redistribution: The Regime Hypothesis Revisited.” European Sociological Review, 22: 157-170.

Shapiro, Robert Y. and John T. Young. 1989. "Public Opinion and the Welfare State: The United States in Comparative Perspective.” Political Science Quarterly 104: 59-89.

Svallfors, Stefan. 1997. "Worlds of Welfare and Attitudes to Redistribution: A Comparison of Eight Western Nations.” European Sociological Review 13: 283-304.

Swenson, Peter. 2002. Capitalists against Markets: The Making of Labor Markets and Welfare States in the United States and Sweden. New York: Oxford UP. 
Table 1: Relationship between pension institutions and expectations

\begin{tabular}{|c|c|c|c|c|c|c|c|c|c|}
\hline & \multicolumn{2}{|c|}{ Diff. of proportion test } & \multicolumn{3}{|c|}{ Statutory contribution rates } & \multicolumn{2}{|c|}{ Difference of means test } & \multicolumn{2}{|c|}{ Difference of means test } \\
\hline & $\begin{array}{c}\text { Public: } \\
\text { Gov. } \\
\text { should pay }\end{array}$ & $\begin{array}{c}\text { Public: } \\
\text { Gov. } \\
\text { will pay }\end{array}$ & Workers & Employers & $\begin{array}{c}\text { Ratio } \\
\text { worker to } \\
\text { employer }\end{array}$ & $\begin{array}{c}\text { Legal } \\
\text { retirement } \\
\text { age } \\
\text { (men) }\end{array}$ & $\begin{array}{c}\text { Ideal } \\
\text { retirement } \\
\text { age } \\
\text { (male) }\end{array}$ & $\begin{array}{c}\text { Legal } \\
\text { retirement } \\
\text { age } \\
\text { (female) }\end{array}$ & $\begin{array}{c}\text { Ideal } \\
\text { retirement } \\
\text { age } \\
\text { (female) }\end{array}$ \\
\hline Brazil & & & 9 & 20 & 0.45 & 65 & $59.8 * *$ & 60 & $54.2^{* *}$ \\
\hline Canada & & & 4.95 & 4.95 & 1 & 60 & $62.2^{* *}$ & 60 & $60.7^{*}$ \\
\hline China & & & 0 & 20 & 0 & 60 & $59.0 * *$ & 60 & $52.9 * *$ \\
\hline Egypt & 0.230 & $0.169 * *$ & 13 & 17 & 0.76 & 60 & $61.0 * *$ & 60 & $50.3 * *$ \\
\hline France & & & 6.55 & 8.2 & 0.80 & 60 & 60.0 & 60 & $57.0^{* *}$ \\
\hline Germany & 0.336 & $0.188 * *$ & 9.55 & 9.55 & 1 & 65 & $63.6^{* *}$ & 65 & $61.3^{* *}$ \\
\hline Hong Kong & & & 0 & 0 & 1 & & & & \\
\hline India & & & 12 & 3.67 & 3.27 & & & & \\
\hline Indonesia & 0.072 & 0.061 & 2 & 3.7 & 0.54 & 55 & $60.1^{* *}$ & 55 & $53.3^{* *}$ \\
\hline Japan & & & 8.68 & 8.68 & 1 & 60 & $65.3^{* *}$ & 60 & $63.1^{* *}$ \\
\hline Malaysia & 0.215 & $0.129 * *$ & 11 & 12 & 0.92 & 55 & $60.4^{* *}$ & 55 & $56.4^{* *}$ \\
\hline Mexico & & & 1.13 & 3.15 & 0.36 & 65 & $61.9 * *$ & 60 & $57.3^{* *}$ \\
\hline Poland & 0.486 & $0.329 * *$ & 9.76 & 9.76 & 1 & 65 & $60.6 * *$ & 60 & $55.4 * *$ \\
\hline Russia & 0.621 & $0.385 * *$ & 0 & 28 & 0 & 60 & $58.4 * *$ & 55 & $53.6 * *$ \\
\hline Saudi Arabia & 0.107 & $0.171 * *$ & 9 & 9 & 1 & 60 & $53.2 * *$ & 55 & $53.2 * *$ \\
\hline Singapore & 0.086 & 0.075 & 20 & 16 & 1.25 & 55 & $63.5^{* *}$ & 55 & $59.8 * *$ \\
\hline Sweden & 0.591 & $0.297 * *$ & 7 & 10.21 & 0.69 & 61 & $63.9 * *$ & 61 & $63.2^{* *}$ \\
\hline Turkey & 0.756 & 0.725 & 9 & 11 & 0.82 & 55 & 54.9 & 50 & $48.4^{* *}$ \\
\hline U.K. & & & 10 & 11.9 & 0.84 & 65 & $63.8 * *$ & 60 & $62.1 * *$ \\
\hline U.S.A. & & & 6.2 & 6.2 & 1 & 65 & 64.9 & 65 & $63.5 * *$ \\
\hline
\end{tabular}

$* \mathrm{p}<0.05, * * \mathrm{p}<0.001$, two-tailed tests.

Sources: Contribution rates and legal retirement ages in 2003 from ILO, Social Security Database, based on Social Security Administration, Social Security Programs throughout the World. 
Table 2: Individual preferences regarding pension reform (multinomial logit)

\begin{tabular}{|c|c|c|c|c|c|c|c|c|c|c|}
\hline & Brazil & Canada & China & Egypt & France & Germany & Hong Kong & India & Indonesia & Japan \\
\hline \multicolumn{11}{|c|}{ Reduce pensions/Enforce additional private savings } \\
\hline $\begin{array}{l}\text { Female } \\
\text { Retired } \\
\text { Unemployed } \\
\text { Student } \\
\text { Homemaker } \\
\text { Age } \\
\text { Income } \\
\text { Constant } \\
\end{array}$ & $\begin{array}{c}0.627 \\
-35.740 \\
-0.476 \\
-0.222 \\
-0.581 \\
-0.166 \\
-0.023 \\
-1.578 * * \\
\end{array}$ & $\begin{array}{c}-0.482 \\
0.490 \\
0.247 \\
-0.186 \\
0.736 \\
-.337^{*} \\
-0.097 \\
-0.225 \\
\end{array}$ & $\begin{array}{c}-0.468 \\
0.099 \\
.891^{*} \\
-0.242 \\
1.100 \\
-0.104 \\
-0.096 \\
0.195 \\
\end{array}$ & $\begin{array}{c}1.087^{*} \\
0.138 \\
-1.166 \\
-0.598 \\
-1.894 \\
-0.353 \\
0.151 \\
-2.469 * * \\
\end{array}$ & $\begin{array}{c}-0.197 \\
-0.645 \\
0.406 \\
-0.083 \\
-0.010 \\
-0.015 \\
-.253^{*} \\
-1.313^{*} \\
\end{array}$ & $\begin{array}{c}-0.203 \\
0.782 \\
1.601^{*} \\
0.884 \\
-0.163 \\
0.019 \\
.206^{*} \\
-4.528^{* * *} \\
\end{array}$ & $\begin{array}{c}-0.468 \\
-0.175 \\
0.772 \\
-0.080 \\
0.338 \\
0.035 \\
-0.063 \\
-1.081^{*} \\
\end{array}$ & $\begin{array}{c}-0.078 \\
-0.050 \\
0.517 \\
-1.247 * \\
-0.102 \\
-0.083 \\
0.006 \\
-1.008 * * \\
\end{array}$ & $\begin{array}{c}-0.617 \\
-1.781 \\
0.389 \\
-0.383 \\
.8267 * \\
-0.028 \\
-0.007 \\
-1.569 * * \\
\end{array}$ & $\begin{array}{c}-0.253 \\
-1.403 \\
-0.050 \\
-38.478 \\
0.289 \\
-0.077 \\
0.023 \\
0.464 \\
\end{array}$ \\
\hline \multicolumn{11}{|c|}{ Raise taxes/Enforce additional private savings } \\
\hline $\begin{array}{l}\text { Female } \\
\text { Retired } \\
\text { Unemployed } \\
\text { Student } \\
\text { Homemaker } \\
\text { Age } \\
\text { Income } \\
\text { Constant }\end{array}$ & $\begin{array}{c}1.454 * \\
0.609 \\
-35.999 \\
0.819 \\
-0.316 \\
-0.149 \\
0.004 \\
-3.512 * * *\end{array}$ & $\begin{array}{c}-0.358 \\
-0.276 \\
-0.143 \\
0.463 \\
-0.665 \\
0.125 \\
-0.011 \\
-1.207 * *\end{array}$ & $\begin{array}{c}-.402 * \\
-0.490 \\
0.611 \\
0.129 \\
0.093 \\
0.050 \\
0.015 \\
0.439\end{array}$ & $\begin{array}{c}0.769 \\
-36.349 \\
3.218^{* * *} \\
-36.299 \\
-36.765 \\
0.027 \\
0.411 \\
-5.876^{* * *}\end{array}$ & $\begin{array}{c}-.777^{*} \\
-0.640 \\
0.577 \\
-32.177 \\
-32.065 \\
0.066 \\
-0.115 \\
-1.337^{*}\end{array}$ & $\begin{array}{c}-0.448 \\
0.796 \\
-1.119 \\
-0.291 \\
-1.436 \\
-.356^{*} \\
0.025 \\
-0.882\end{array}$ & $\begin{array}{c}-0.397 \\
0.337 \\
0.486 \\
-0.771 \\
0.174 \\
-0.060 \\
0.000 \\
-0.468\end{array}$ & $\begin{array}{c}0.172 \\
0.654 \\
0.256 \\
-0.615 \\
-0.522 \\
-0.144 \\
0.029 \\
-.946 * *\end{array}$ & $\begin{array}{c}-0.396 \\
-0.592 \\
-0.714 \\
0.019 \\
-0.321 \\
-0.013 \\
0.109 \\
-1.299 * *\end{array}$ & $\begin{array}{c}-0.758 \\
0.362 \\
0.677 \\
-38.018 \\
0.319 \\
-0.150 \\
.2380 * * \\
0.161\end{array}$ \\
\hline \multicolumn{11}{|c|}{ Increase retirement age/Enforce additional private savings } \\
\hline $\begin{array}{l}\text { Female } \\
\text { Retired } \\
\text { Unemployed } \\
\text { Student } \\
\text { Homemaker } \\
\text { Age } \\
\text { Income } \\
\text { Constant } \\
\end{array}$ & $\begin{array}{c}0.030 \\
0.257 \\
-0.219 \\
0.192 \\
-0.226 \\
0.119 \\
-0.048 \\
-1.762 * * * \\
\end{array}$ & $\begin{array}{c}0.062 \\
-0.301 \\
-0.074 \\
0.740 \\
-0.190 \\
.249 * * * \\
-0.013 \\
-1.168 * * \\
\end{array}$ & $\begin{array}{c}0.120 \\
0.261 \\
-0.088 \\
0.793 \\
-0.251 \\
0.070 \\
-0.047 \\
-0.007 \\
\end{array}$ & $\begin{array}{c}-0.256 \\
-0.022 \\
1.438 * * * \\
0.879 \\
-0.016 \\
.224 * \\
0.053 \\
-2.572^{* * *} \\
\end{array}$ & $\begin{array}{c}-0.131 \\
-0.192 \\
0.668 \\
0.590 \\
-0.836 \\
.357 * * \\
0.103 \\
-2.981^{* * *} \\
\end{array}$ & $\begin{array}{c}-.560^{*} \\
0.175 \\
-0.510 \\
0.202 \\
0.453 \\
0.045 \\
0.092 \\
-2.304^{* * *} \\
\end{array}$ & $\begin{array}{c}0.008 \\
0.171 \\
-0.081 \\
-0.448 \\
0.415 \\
0.127 \\
-.067 * \\
-0.253 \\
\end{array}$ & $\begin{array}{c}0.082 \\
0.575 \\
0.123 \\
-0.027 \\
0.030 \\
-.157^{*} \\
0.036 \\
-0.260 \\
\end{array}$ & $\begin{array}{c}-0.022 \\
-0.157 \\
-0.108 \\
-0.519 \\
-0.077 \\
-.185 * * \\
0.015 \\
.590 * \\
\end{array}$ & $\begin{array}{c}-0.170 \\
-0.362 \\
-0.553 \\
-0.510 \\
0.258 \\
0.017 \\
0.049 \\
1.374 * \\
\end{array}$ \\
\hline Pseudo R2 & 0.035 & 0.023 & 0.028 & 0.090 & 0.048 & 0.033 & 0.024 & 0.009 & 0.016 & 0.027 \\
\hline Chi2 & 33.270 & 39.905 & 56.665 & 59.183 & 56.995 & 36.299 & 51.595 & 28.879 & 35.654 & 37.397 \\
\hline Df & 21.000 & 21.000 & 21.000 & 21.000 & 21.000 & 21.000 & 21.000 & 21.000 & 21.000 & 21.000 \\
\hline $\mathrm{N}$ & 521.000 & 719.000 & 767.000 & 474.000 & 582.000 & 722.000 & 846.000 & 1281.000 & 959.000 & 598.000 \\
\hline
\end{tabular}

(Continued on next page) 
Table 2 (continued)

\begin{tabular}{|c|c|c|c|c|c|c|c|c|c|c|}
\hline & Malaysia & Mexico & Poland & Russia & $\begin{array}{l}\text { Saudi } \\
\text { Arabia }\end{array}$ & Singapore & Sweden & Turkey & UK & USA \\
\hline \multicolumn{11}{|c|}{ Reduce pensions/Enforce additional private savings } \\
\hline $\begin{array}{l}\text { Female } \\
\text { Retired } \\
\text { Unemployed } \\
\text { Student } \\
\text { Homemaker } \\
\text { Age } \\
\text { Income } \\
\text { Constant } \\
\end{array}$ & $\begin{array}{c}0.211 \\
0.102 \\
1.061^{*} \\
0.698 \\
0.127 \\
0.016 \\
-.1584785^{*} \\
-1.014 \\
\end{array}$ & $\begin{array}{c}-1.273 * * \\
1.178 \\
-0.092 \\
0.728 \\
1.198 * \\
-0.021 \\
-0.040 \\
-1.537 * * \\
\end{array}$ & $\begin{array}{c}-0.639 \\
- \\
-0.863 \\
0.277 \\
0.355 \\
.638 * * \\
-0.151 \\
-3.115^{* *} \\
\end{array}$ & $\begin{array}{c}0.176 \\
-0.467 \\
-0.243 \\
0.256 \\
-35.994 \\
0.330 \\
-0.150 \\
-3.072 * \\
\end{array}$ & $\begin{array}{c}-0.648 \\
1.479 \\
0.377 \\
1.743^{* *} \\
0.472 \\
0.053 \\
-0.097 \\
-2.701^{* *} \\
\end{array}$ & $\begin{array}{c}-0.299 \\
0.397 \\
-33.538 \\
-0.408 \\
-0.348 \\
0.116 \\
-.122^{*} \\
-0.798 \\
\end{array}$ & $\begin{array}{c}0.116 \\
-0.391 \\
0.337 \\
-1.901 \\
-31.946 \\
-0.030 \\
-.254 * * \\
0.164 \\
\end{array}$ & $\begin{array}{c}-0.698 \\
-0.199 \\
0.505 \\
-0.577 \\
0.005 \\
-0.147 \\
0.000 \\
-0.490 \\
\end{array}$ & $\begin{array}{c}-0.840 \\
-1.227 \\
0.805 \\
2.271^{*} \\
0.040 \\
-.304^{*} \\
-0.842 \\
\end{array}$ & $\begin{array}{c}-0.578 \\
-0.001 \\
-0.960 \\
-0.203 \\
-0.506 \\
-0.215 \\
-0.076 \\
0.126 \\
\end{array}$ \\
\hline \multicolumn{11}{|c|}{ Raise taxes/Enforce additional private savings } \\
\hline $\begin{array}{l}\text { Female } \\
\text { Retired } \\
\text { Unemployed } \\
\text { Student } \\
\text { Homemaker } \\
\text { Age } \\
\text { Income } \\
\text { Constant } \\
\end{array}$ & $\begin{array}{c}0.078 \\
0.567 \\
0.198 \\
-0.574 \\
.818^{*} \\
-0.172 \\
-0.118 \\
-0.209 \\
\end{array}$ & $\begin{array}{c}-0.396 \\
0.383 \\
0.310 \\
-0.749 \\
-0.523 \\
0.106 \\
-0.028 \\
-1.477^{* *} \\
\end{array}$ & $\begin{array}{c}-0.473 \\
-0.535 \\
-0.355 \\
-0.036 \\
0.199 \\
0.076 \\
-.116^{*} \\
-0.485 \\
\end{array}$ & $\begin{array}{c}0.120 \\
0.596 \\
0.000 \\
-0.195 \\
-0.135 \\
0.080 \\
-0.018 \\
-1.060 \\
\end{array}$ & $\begin{array}{c}-1.856^{*} \\
-31.382 \\
0.885 \\
0.459 \\
0.839 \\
-0.010 \\
-0.001 \\
-2.465^{* *} \\
\end{array}$ & $\begin{array}{c}-0.053 \\
-0.272 \\
-0.434 \\
0.863 \\
-0.833 \\
0.194 \\
0.029 \\
-2.135^{* * *} \\
\end{array}$ & $\begin{array}{c}.455 * \\
-0.619 \\
-0.769 \\
-1.319 * * \\
-0.764 \\
0.022 \\
-.170 * * \\
1.144 * \\
\end{array}$ & $\begin{array}{c}0.006 \\
-0.110 \\
0.431 \\
0.253 \\
-0.262 \\
0.041 \\
-0.103 \\
-0.563 \\
\end{array}$ & $\begin{array}{c}-0.223 \\
-0.433 \\
0.194 \\
-40.385 \\
\\
0.070 \\
-0.050 \\
-0.106 \\
\end{array}$ & $\begin{array}{c}0.262 \\
-.886^{*} \\
-0.865 \\
-1.282 \\
-0.686 \\
0.083 \\
0.005 \\
-.953^{*} \\
\end{array}$ \\
\hline \multicolumn{11}{|c|}{ Increase retirement age/Enforce additional private savings } \\
\hline $\begin{array}{l}\text { Female } \\
\text { Retired } \\
\text { Unemployed } \\
\text { Student } \\
\text { Homemaker } \\
\text { Age } \\
\text { Income } \\
\text { Constant } \\
\end{array}$ & $\begin{array}{c}0.254 \\
0.503 \\
0.512 \\
-0.312 \\
-0.506 \\
-0.021 \\
-.104^{*} \\
-0.059 \\
\end{array}$ & $\begin{array}{c}-0.405 \\
0.175 \\
0.000 \\
-0.275 \\
0.012 \\
.166^{*} \\
-.090^{*} \\
-0.581 \\
\end{array}$ & $\begin{array}{c}-0.132 \\
-0.670 \\
0.010 \\
0.909 \\
-0.471 \\
0.218 \\
-0.078 \\
-1.505^{*} \\
\end{array}$ & $\begin{array}{c}0.258 \\
0.543 \\
0.516 \\
-0.148 \\
-0.085 \\
0.019 \\
0.083 \\
-1.861^{* *} \\
\end{array}$ & $\begin{array}{c}-.578 * \\
0.508 \\
0.467 \\
-0.048 \\
0.109 \\
-0.134 \\
-0.026 \\
-0.116 \\
\end{array}$ & $\begin{array}{c}-0.092 \\
-0.023 \\
-0.455 \\
0.379 \\
0.327 \\
0.085 \\
-.070^{*} \\
0.437 \\
\end{array}$ & $\begin{array}{c}0.111 \\
-0.446 \\
0.119 \\
-0.203 \\
-32.008 \\
0.148 \\
-.155^{*} \\
-0.073 \\
\end{array}$ & $\begin{array}{c}-0.021 \\
0.460 \\
0.397 \\
0.787 \\
-0.143 \\
0.039 \\
-0.017 \\
-0.354 \\
\end{array}$ & $\begin{array}{c}-0.219 \\
-0.202 \\
0.547 \\
1.064 \\
0.060 \\
-.116^{*} \\
0.080 \\
\end{array}$ & $\begin{array}{c}0.286 \\
0.187 \\
0.367 \\
-0.126 \\
-0.008 \\
0.133 \\
-0.015 \\
-1.047^{*} \\
\end{array}$ \\
\hline Pseudo R2 & 0.026 & 0.030 & 0.030 & 0.019 & 0.031 & 0.023 & 0.025 & 0.017 & 0.022 & 0.032 \\
\hline Chi2 & 38.036 & 43.473 & 27.142 & 23.916 & 34.265 & 34.709 & 43.366 & 27.446 & 35.483 & 47.981 \\
\hline $\mathrm{Df}$ & 21 & 21 & 21 & 21 & 21 & 21 & 21 & 21 & 18 & 21 \\
\hline $\mathrm{N}$ & 590 & 628 & 424 & 572 & 649 & 651 & 701 & 624 & 670 & 585 \\
\hline
\end{tabular}

$* \mathrm{p}<.05, * * \mathrm{p}<.01$, and $* * * \mathrm{p}<.001$ 
Table 3: Firm preferences regarding pension reform (multinomial logit)

\begin{tabular}{|c|c|c|c|c|c|c|c|c|c|c|}
\hline & Pooled & Brazil & Mexico & Canada & UK & USA & France & Germany & Sweden & Turkey \\
\hline \multicolumn{11}{|c|}{ Reduce pensions/Enforce additional private savings } \\
\hline $\begin{array}{l}\text { Revenue } \\
\text { Firm size } \\
\text { Secondary sector } \\
\text { Tertiary sector } \\
\text { Foreign ownership } \\
\text { Constant }\end{array}$ & $\begin{array}{c}.003 \\
-.186 \\
.781 \\
.393 \\
-.273 \\
-2.204 * * * \\
\end{array}$ & $\begin{array}{c}0.141 \\
-0.278 \\
19.137 * * * \\
19.438^{* * *} \\
\\
-21.858 \\
\end{array}$ & $\begin{array}{c}-0.213 \\
-0.334 \\
-1.618 \\
\\
1.016 \\
-1.373 \\
\end{array}$ & $\begin{array}{c}-0.029 \\
0.193 \\
19.689^{* * *} \\
17.961^{* * *} \\
0.019 \\
-22.012 \\
\end{array}$ & $\begin{array}{c}0.604 \\
-22.970 \\
-47.016 \\
-6.047 \\
-41.661 \\
24.733 \\
\end{array}$ & $\begin{array}{c}-0.216 \\
0.582 \\
18.875 \\
19.104 * * * \\
-33.983 \\
- \\
\end{array}$ & $\begin{array}{c}0.522 \\
-1.431 \\
-17.562 \\
22.124^{* * *} \\
-37.125 \\
-25.822 \\
\end{array}$ & $\begin{array}{c}0.353 \\
41.334 * * * \\
-66.592 \\
-105.868 \\
1.094 \\
-63.015 \\
\end{array}$ & $\begin{array}{c}0.005 \\
0.474 \\
-0.757 \\
0.086 \\
1.057 \\
-3.216^{*} \\
\end{array}$ & $\begin{array}{c}-0.254 \\
0.560 \\
-38.292 \\
-0.573 \\
-36.867 \\
-1.837 \\
\end{array}$ \\
\hline $\begin{array}{l}\text { Revenue } \\
\text { Firm size } \\
\text { Secondary sector } \\
\text { Tertiary sector } \\
\text { Foreign ownership } \\
\text { Constant } \\
\end{array}$ & $\begin{array}{c}.009 \\
-.192 \\
.0419 \\
.296 \\
-.040 \\
-1.444 * * * \\
\end{array}$ & $\begin{array}{c}-0.139 \\
0.083 \\
22.098 * * * \\
-11.865 \\
\\
-24.967 \\
\end{array}$ & $\begin{array}{c}0.222 \\
0.717 \\
-\end{array}$ & $\begin{array}{c}-0.015 \\
0.234 \\
18.867 * * * \\
19.034 * * * \\
-1.082 \\
-20.830 \\
\end{array}$ & $\begin{array}{c}-0.076 \\
-0.509 \\
17.079 * * * \\
17.329 * * * \\
-0.351 \\
-16.295 \\
\end{array}$ & $\begin{array}{c}-0.087 \\
-0.477 \\
18.487 \\
19.285^{* * *} \\
0.794 \\
- \\
\end{array}$ & $\begin{array}{c}-0.070 \\
0.343 \\
-1.718 \\
-0.135 \\
1.075 \\
-2.155 \\
\end{array}$ & $\begin{array}{c}-0.265 \\
0.199 \\
24.284 \\
-16.038 \\
-0.433 \\
- \\
\end{array}$ & $\begin{array}{c}-0.158 \\
0.173 \\
- \\
- \\
0.975 \\
19.648\end{array}$ & $\begin{array}{c}-0.101 \\
- \\
0.429 \\
-0.522 \\
-36.682 \\
17.792 \\
\end{array}$ \\
\hline \multicolumn{11}{|c|}{ Increase retirement age/ Enforce additional private savings } \\
\hline $\begin{array}{l}\text { Revenue } \\
\text { Firm size } \\
\text { Secondary sector } \\
\text { Tertiary sector } \\
\text { Foreign ownership } \\
\text { Constant } \\
\end{array}$ & $\begin{array}{c}.076 * * * \\
-.205 * * \\
.166 \\
.260 \\
.059 \\
-.793 * * \\
\end{array}$ & $\begin{array}{c}0.432 \\
-1.154 \\
19.251^{* * *} \\
18.731^{* * *} \\
\\
-21.451 \\
\end{array}$ & $\begin{array}{c}-0.050 \\
0.091 \\
-0.223 \\
0.376 \\
-1.047 * \\
\end{array}$ & $\begin{array}{c}-0.026 \\
0.040 \\
-1.025 \\
-0.960 \\
0.241 \\
0.594 \\
\end{array}$ & $\begin{array}{c}0.050 \\
-0.166 \\
17.178^{* * *} \\
17.571^{* * *} \\
0.144 \\
-17.559 \\
\end{array}$ & $\begin{array}{c}0.074 \\
-0.377 \\
18.965 \\
19.039 * * * \\
-0.024 \\
- \\
\end{array}$ & $\begin{array}{c}0.096 \\
-0.055 \\
0.748 \\
1.109 \\
0.218 \\
-2.489 * \\
\end{array}$ & $\begin{array}{c}-0.023 \\
-0.491 \\
19.368 \\
19.814^{* * *} \\
-1.110 \\
- \\
\end{array}$ & $\begin{array}{c}-0.107 \\
0.237 \\
0.099 \\
0.280 \\
-0.008 \\
-0.473 \\
\end{array}$ & $\begin{array}{c}0.025 \\
0.713 \\
-37.935 \\
0.094 \\
-0.888 \\
-1.328 * \\
\end{array}$ \\
\hline Pseudo R2 & .007 & 0.081 & 0.067 & 0.033 & 0.047 & 0.028 & 0.057 & 0.182 & 0.050 & 0.056 \\
\hline Chi2 & 38.747 & 7.806 & 20.831 & 9.902 & 16.047 & 14.912 & 11.374 & 31.501 & 15.030 & 15.538 \\
\hline df & 15 & 12 & 12 & 15 & 15 & 15 & 15 & 15 & 15 & 15 \\
\hline $\mathrm{N}$ & 2426 & 85 & 167 & 145 & 152 & 255 & 121 & 125 & 128 & 132 \\
\hline
\end{tabular}

(Continued on next page) 
Table 3: continued from previous page

\begin{tabular}{|c|c|c|c|c|c|c|}
\hline & India & China & Indonesia & Hong Kong & Japan & Singapore \\
\hline \multicolumn{7}{|c|}{ Reduce pensions/Enforce additional private savings } \\
\hline $\begin{array}{l}\text { Revenue } \\
\text { Firm size } \\
\text { Secondary sector } \\
\text { Tertiary sector } \\
\text { Foreign ownership } \\
\text { Constant }\end{array}$ & $\begin{array}{c}0.041 \\
-0.675 \\
-0.570 \\
-1.195^{*} \\
-32.343 \\
0.490\end{array}$ & $\begin{array}{c}0.005 \\
-0.401 \\
0.757 \\
-0.604 \\
-0.969\end{array}$ & $\begin{array}{c}-0.193 \\
0.300 \\
18.474 * * * \\
18.212 * * * \\
-0.428 \\
-20.008\end{array}$ & $\begin{array}{c}-0.095 \\
0.344 \\
18.406 \\
17.248 * * * \\
-1.116 \\
-19.216 * * *\end{array}$ & $\begin{array}{c}0.047 \\
0.382 \\
0.073 \\
-0.562 \\
-0.981\end{array}$ & $\begin{array}{c}-0.160 \\
-0.279 \\
-20.644 \\
-21.064 * * * \\
0.278 \\
20.347 * * *\end{array}$ \\
\hline \multicolumn{7}{|c|}{ Raise taxes/ Enforce additional private savings } \\
\hline $\begin{array}{l}\text { Revenue } \\
\text { Firm size } \\
\text { Secondary sector } \\
\text { Tertiary sector } \\
\text { Foreign ownership } \\
\text { Constant }\end{array}$ & $\begin{array}{c}0.189 \\
-1.044869 * \\
-0.632 \\
-2.070848 * \\
-32.054 \\
-0.020\end{array}$ & $\begin{array}{c}0.359 \\
-0.445 \\
0.551 \\
\\
-0.702 \\
-0.542\end{array}$ & $\begin{array}{c}-.667^{* *} \\
.920^{*} \\
-2.124 \\
-1.166 \\
2.034^{* *} \\
-1.298 \\
\end{array}$ & $\begin{array}{c}-0.235 \\
0.648 \\
18.714 \\
18.788 * * * \\
-0.683 \\
-20.527 * * *\end{array}$ & $\begin{array}{c}0.273 \\
-0.285 \\
-19.379^{* * *} \\
-19.536^{* * *} \\
\\
17.450\end{array}$ & $\begin{array}{c}-0.033 \\
0.413 \\
0.251 \\
-0.817 \\
-0.310 \\
-1.828 *\end{array}$ \\
\hline \multicolumn{7}{|c|}{ Increase retirement age/ Enforce additional private savings } \\
\hline $\begin{array}{l}\text { Revenue } \\
\text { Firm size } \\
\text { Secondary sector } \\
\text { Tertiary sector } \\
\text { Foreign ownership } \\
\text { Constant }\end{array}$ & $\begin{array}{c}-0.060 \\
-0.118 \\
-19.030^{* * *} \\
-19.601^{* * *} \\
-32.870 \\
18.969\end{array}$ & $\begin{array}{c}.479 * \\
-1.038 \\
1.824 \\
\\
0.279 \\
-1.411\end{array}$ & $\begin{array}{c}-0.179 \\
0.434 \\
-0.340 \\
-0.521 \\
0.327 \\
-1.069\end{array}$ & $\begin{array}{c}-0.038 \\
-0.256 \\
18.931 \\
18.976^{* * *} \\
-0.687 \\
-18.263^{* * *}\end{array}$ & $\begin{array}{c}0.016 \\
0.339 \\
-0.117 \\
-0.324 \\
\\
0.558\end{array}$ & $\begin{array}{c}0.136 \\
-0.328 \\
0.494 \\
0.126 \\
.852 * \\
-0.659\end{array}$ \\
\hline Psuedo R2 & 0.051 & 0.063 & 0.054 & 0.059 & 0.020 & 0.056 \\
\hline Chi2 & 21.756 & 11.385 & 27.033 & 17.008 & 9.285 & 18.838 \\
\hline $\mathrm{df}$ & 15 & 12 & 15 & 15 & 12 & 15 \\
\hline $\mathrm{N}$ & 186 & 70 & 251 & 125 & 183 & 143 \\
\hline
\end{tabular}




\section{Data appendix}

The survey that we analyze was conducted in April 2006 by the Oxford Institute of Aging and the HSBC Bank. Titled “The Future of Retirement”, the survey was intended to probe how individuals and firms viewed retirement, older workers, and pension policies. The survey was conducted in 20 countries across 5 continents, including countries that make up $60 \%$ of the world's population. A further unique aspect of the survey is that it included a firm-level component. In addition to fielding a standard national sample of 1,000 individuals, the survey was also administered among a sample of small, medium, and large firms in the same 20 countries. In each country, the most senior HR representatives in approximately 300 firms were asked their opinions, based on the interests of the company, on retirement and pensions. Such surveys of firms are relatively uncommon and few of them have a wide cross-national scope. Finally, the survey probes a specific policy area in depth. It focuses entirely on retirement and pensions and asks a number of specific questions about pension reform. Unlike most other studies that look at general attitudes towards redistribution or support for the welfare state, it allows us to link opinions in a specific policy area with past and future policies in that area.

The study does have several drawbacks. The survey was sponsored by the HSBC Bank presumably with the intention of supplying useful information to its insurance division. It was fielded, however, with the cooperation of the Oxford Institute on Aging and a professional polling firm, Harris International. Potential biases should be clear in the question wording. More important, the survey lacks many important questions that could be used to explain preferences. There are, for example, no political or general ideological questions. Questions on policy options, moreover, are not framed as tradeoffs but rather as mutually exclusive choices. The study therefore does not allow a probing of more subtle policy choices or strategies as, for example, in Boeri, Supan-Bosch, and Tabellini (2001). Nevertheless, the cross-national coverage and inclusion of firms along with a handful of interesting questions do allow useful analyses that have not yet been conducted. 


\section{RECENT WORKING PAPERS FROM THE}

\section{CENTER FOR RETIREMENT RESEARCH AT BOSTON COLLEGE}

The Long-Term Effect of the Divorce Revolution: Health, Wealth, and Labor Supply

Kristin Mammen, December 2008

The Response of Household Saving to the Large Shock of German Reunification Nicola Fuchs-Schündeln, November 2008

A Parsimonious Choquet Model of Subjective Life Expectancy

Alexander Ludwig and Alexander Zimper, November 2008

Risky Pensions and Household Saving Over the Life Cycle

David A. Love and Paul A. Smith, November 2008

Identifying Local Differences in Retirement Patterns

Leora Friedberg, Michael Owyang, and Anthony Webb, November 2008

What Effect Do Time Constraints Have on the Age of Retirement?

Leora Friedberg, Wei Sun, Anthony Webb, November 2008

Dual-Eligible Medicaid Spending: Are We on the Flat of the Curve?

Melissa A. Boyle, Joanna N. Lahey, and Margaret E. Czervionke, November 2008

Public Long-Term Care Insurance and the Housing and Living Arrangements of the Elderly: Evidence from Medicare Home Health Benefits

Gary V. Engelhardt and Nadia Greenhalgh-Stanley, November 2008

The Impact of Changing Earnings Volatility on Retirement Wealth

Austin Nichols and Melissa M. Favreault, November 2008

The Housing Bubble and Retirement Security

Alicia H. Munnell and Mauricio Soto, with the assistance of Jean-Pierre Aubry, November 2008

How Much Do State and Economic and Other Characteristics Affect Retirement Behavior?

Alicia H. Munnell, Mauricio Soto, Robert K. Triest, and Natalia A. Zhivan, August 2008

All working papers are available on the Center for Retirement Research website

(http://www.bc.edu/crr) and can be requested by e-mail (crr@bc.edu) or phone (617-552-1762). 